\title{
流砂の衝突回数を考慮したハイドロフォン データによる解析手法の提案と現地への適用
}

\author{
長谷川 祐治 1 - 宮田 秀介 $2 \cdot$ 今泉 文寿 $3 \cdot$ 中谷 加奈 $4 \cdot$ 堤 大三 5 \\ 1 正会員 京都大学防災研究所 特任助教（干612-8235 京都市伏見区横大路下三栖東ノ口） \\ E-mail: hasegawa.yuji.3e@kyoto-u.ac.jp \\ 2 正会員 京都大学防災研究所 助教（干612-8235 京都市伏見区横大路下三栖東ノ口） \\ E-mail:miyata.shusuke.2e@kyoto-u.ac.jp \\ 3 非会員 静岡大学農学部 准教授（干422-8529 静岡市駿河区大谷 836） \\ E-mail:imaizumi@shizuoka.ac.jp \\ 4 正会員 京都大学大学院農学研究科 助教（干606-8502 京都市左京区北白川追分町） \\ E-mail:kana2151@kais.kyoto-u.ac.jp \\ 5 正会員 京都大学防災研究所 准教授（干506-1422 岐阜県高山市奥飛騨温泉郷中尾 436-13） \\ E-mail:tsutsumi.daizo.8m@kyoto-u.ac.jp
}

\begin{abstract}
ハイドロフォンによる流砂量解析には，流砂の衝突回数（パルス数）を記録する方法が用いられる。し かし, 流砂量が多い状態では全ての流砂がハイドロフォンに衝突しても管内で音が飽和してパルス数が検 出され難くなり，流砂量を少なく評価することが課題に挙げられる．本研究ではパルスの記録方法を検討 して，パルス数が最も多く記録される閾值で評価するMethod 1 と，閾值毎に記録されたパルス数で評価す るMethod 2 の 2 つの手法を確認した。現地観測の結果を基に両者を検証して，Method 2 で解析したパルス 数は流砂量が多い状態でも検出されやすいことを明らかにした。 また，この手法から得られた流砂量を基 に数值シミュレーションを実施して観測と計算を連携させるために必要な情報を整理した.
\end{abstract}

Key Words: measurement sediment discharge, hydrophone, collision frequency, field measurement, numerical simulation

\section{1. はじめに}

日本では 1970 年頃から本格的な流砂量観測が実施さ れ，1990年代から山地河川への設置がはじまったハイド ロフォンは近年計測が盛んに行われ，観測データが蓄積 されてきた 1,22. 八イドロフォンを用いた流砂量計測は, 図-1 に示寸流砂がハイドロフォンに衝突する際に生じ る音響信号を得るセンサ一部，音響信号の波形を整形す る一次処理, デジタル信号に変換後, 流砂量を推定する ための二次処理から構成される. 二次処理には流砂の衝 突回数（パルス数）を記録する方法，振幅の時間積分值 を記録する方法がある．谷口・板倉 ${ }^{3}$ は連続衝突や残響 が長引く大礫の衝突に対して検出率 (パルス数流砂量, 積分值流砂量）の低下を確認して，流砂量が多くなる と積分值の検出率の落込みがより大きくなることを示し た. 鈴木ら ${ }^{4}$ は積分值を記録する方法でハイドロフォン に衝突する粒子数から検出率の低下を考慮した手法を考
案し，現地で直接採取した流砂量と比較して良い相関が 得られたことを報告した．一方で，谷口・板倉 ${ }^{3)}$ の検討 後にパルス数を記録する方法が広まり，パルス数から流 砂量を推定する検討が多数実施されている例泣5)。. しか し, 流砂量が多い状態ではパルス数と流砂量にも良い相 関が得られない。この理由は，計測レンジの超過，検出

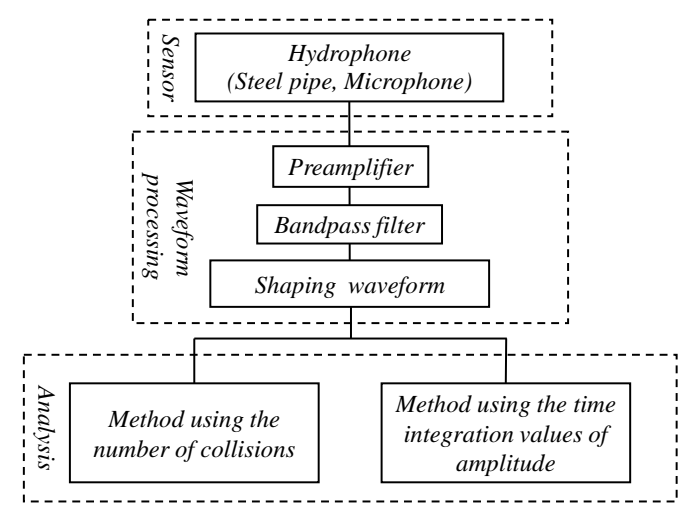

図-1 ハイドロフォンシステムの構成. 
率の低下，ハイドロフォンに衝突しない粒子が多い，な ど様々な要因が挙げられるが，詳細は明らかにされてい ない. 現状の流砂観測ではパルスによる記録が主流であ り, 前述の課題を解決することは流砂量を推定する上で 不可欠である. 本研究では, パルス数から流砂量を推定 することを目的に，パルスの記録方法を詳細に確認する とともに, 現地観測データからパルス数と流砂量を比較 検証し，パルスの記録方法について考察を行った.

これらの情報を基に，土砂動態を把握するための第一 歩として数值シミュレーションを実施した. 既往研究で は土砂動態の把握には数值シミュレーションが有効なツ 一ルとして使用されるが7,8)，上流からの境界条件の設 定方法が結果に大きく影響するにも関らず，十分な情報 がないことから大胆な仮定，例えば，平衡土砂量を供給 することが散見される．精度の高い流砂量データが観測 から得られれば，計算と連携させることで境界条件の設 定や結果の検証が可能となり, 双方の精度向上が期待さ れるが，そのような検討事例は少ない，本研究では，現 地観測で得られたハイドロフォンの結果を用いて計算を 行った場合と, 従来の推定手法で条件を設定した場合の 比較検証を行い，計算と観測を連携させるために必要な 情報の整理を行った.

\section{2. パルスの記録方法}

パルスを記録するには音響信号のような連続量に対し てある闇值を設けて, 離散化して処理を行う。具体的に は，100kHz で記録した音響信号を円周方向に伝播する 音の周波数帯をバンドパスフィルタで抽出し, 得られた 信号の正の極值を全て検出し，それらを結んで波形を整 形する作業を4回繰り返す，整形された波形は，図-2の ように一定の閾値に対して信号を増幅させる方法と図-3 のように 1 つの信号に対して複数の閯值を設定する 2 通 の方法がある. パルス数は波形が閾值を上回った時に 1

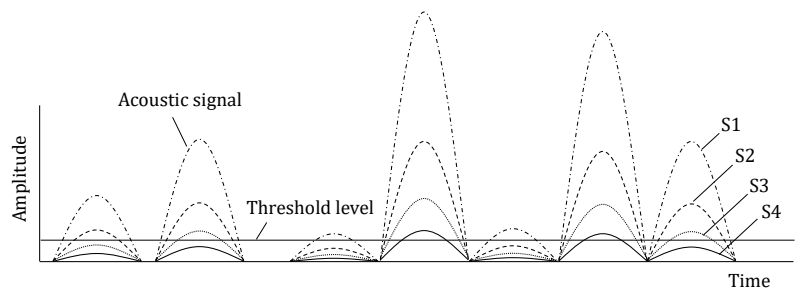

図-2 パルス数の記録方法（信号を増幅させる場合）．

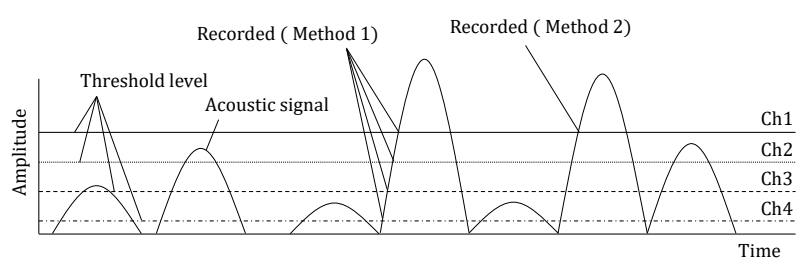

図-3 パルス数の記録方法（閾值を複数設定する場合）.
回と記録される. 両者は, 信号の処理方法が異なるだけ で, 同様にパルス数が記録される.

一般には，高倍率の Ch は小さい閾值に，低倍率の Ch は大きい閾值に対応する，例えば，図-2 のS1 の波形は 図-3 の Ch4 の闇值に，S2 は Ch3 に，S3 はCh2 に，S4 は Ch1 にそれぞれ対応する. パルス数の出力方法も 2 通り ある. 図-3 で説明すると，信号がそれぞれの閾值を上 回った時にパルスを記録する方法（以下，Method 1 と呼 ぶ）と，信号がある閾值（例えば，Ch2）を上回り，次 に大きい閾值（例えば，Ch1）を上回らない場合に Ch2 でパルスを記録する方法（以下, Method2 と呼ぶ）であ る. すなわち，最大の閯值のみでパルス数を記録する方 法である. 計測時間内において, 前者はパルス数が最も 多く記録される闇值 $(\mathrm{Ch})$ で評価し，後者は，閯值ご とに記録されるパルス数で評価する，ここで，図-3に ある信号と閾值の関係からパルス数を整理すると，

Method 1 では (Ch1, Ch2, Ch3, Ch4) = (2, 4, 5, 7), Method2では (2，2，1，2）である. Method1ではパルス 数の最大值が 7 回で, Method 2 ではパルス数の合計が 7 回と，同数になる．また，衝突頻度が低く，波形が重な らない場合は Method 1 では最小の閾值（Ch4）で必ずパ ルスが記録されるため最大值となる. 現在, 現地で運用 されているハイドロフォンシステムは，ほとんどが Method1である.

Method 1 の特性から，大きい閾值から小さい閾值で記 録されたパルス数の差をとり, その值がゼロに近ければ 波形が 1 つの閾值を下回ってその間では波形が重なら ない状態，プラスの值が大きければ振幅值が 1 つの閾

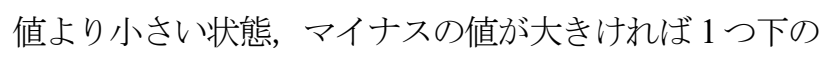
閾值を下回らずに信号が飽和状態となりパルスが検出さ れないと推測できる. Method 1 で記録したパルス数から Method 2 のパルス数を導くには, 下式に示すように倍率 の小さい閾值からのパルス数の差を取る.

$$
\begin{aligned}
&(\mathrm{Ch} 1)_{m 2}=(\mathrm{Ch} 1)_{m 1} \\
&(\mathrm{Ch} 2)_{m 2}=(\mathrm{Ch} 2)_{m 1}-(\mathrm{Ch} 1)_{m 2} \\
&(\mathrm{Ch} 3)_{m 2}=(\mathrm{Ch} 3)_{m 1}-(\mathrm{Ch} 2)_{m 2}-(\mathrm{Ch} 1)_{m 2} \\
&(\mathrm{Ch} 4)_{m 2}=(\mathrm{Ch} 4)_{m 1}-(\mathrm{Ch} 3)_{m 2} \\
&-(\mathrm{Ch} 2)_{m 2}-(\mathrm{Ch} 1)_{m 2}
\end{aligned}
$$

（）は各 Ch のパルス数を表し，負になる場合の扱いは 議論の余地が残されるが，本解析ではゼロとする．添え 字 $\mathrm{m} 1$ は Method 1，m2 は Method 2である. 例えば，図-3 からパルス数を求めると, Method 1 の $(2,4 ， 5 ， 7)$ か らMethod 2 (2，2，1，2）を求めることができる. 


\section{3. 流砂観測データを用いた解析手法の検証}

前述の 2 通りの方法について，現地観測データを用い て検証を行った. 現地観測の概要を以下に示す.

図-4 に対象区間の縦断図を示す．図中の数值は各区 間の勾配である. 観測は神通川水系足洗谷試験流域内の ヒル谷で， 2015 年 11 月 25 日に実施した. ヒル谷には排 砂ゲートを備えた試験堰堤があり，堰堤上流の沈砂池に 堆積した土砂を排出して, 給砂を行った. 流量を一定と するために，実験中はゲート操作を行わず，人力にて排 砂を行った．給砂時間は 10:15 から 14:40の約 4.5 時間で, 総排出土砂量は実験前後の沈砂池の測量結果から空隙込 みで $21.8 \mathrm{~m}^{3}$ ，流量は $0.05 \mathrm{~m}^{2} / \mathrm{s}$ である．堰堤の下流約 $20 \mathrm{~m}$ に位置する道路を横断する暗渠の入口にハイドロフォン を縦方向に設置した（以下，縦型ハイドロフォンと呼 ぶ) . 堰堤から約 $46 \mathrm{~m}$ 下流にある落差工を利用して, 手持ちのハイドロフォン (以下，可搬型ハイドロフォン と呼ぶ）と Helley-Smith式採砂器9で直接採取した. 縦型 ハイドロフォンは，ステンレス製の円管で，長さ $50 \mathrm{~cm}$, 内径 $4.6 \mathrm{~cm}$, 片側にマイクロフォンを取り付けた. 音響 信号の処理を行わず，キャリブレーションを実施してい ないため, 定性計測に留まる.ここでは, 波形が暗渠に 流出寸る流砂のハイドロと同じと仮定した. 可搬型八イ ドロフォンは，ステンレス製の L 字型の円管で，横方向 の長さ $20 \mathrm{~cm}$, 縦方向の長さ $20 \mathrm{~cm}$, 内径 $2.1 \mathrm{~cm}$, 横方向 の先端部には電磁流速計を, 縦方向の先端部にコンデン サー式のマイクロフォンを取り付けた。 流砂量解析を行 うため，音響信号はマイクロフォンからプリアンプやフ イルターを通じてデータロガー(Keyence, NR-2000)で記 録して，6段階に増幅した. システム自体は現地にある 一般的なハイドロフォンをほぼ同じ仕様であり, 定量計 測が行える. 図-5 にハイドロフォンの模式図を示す. 計測時は図-4 の写真のように手持ちで可搬型ハイドロ フォンを置いて，10秒間計測を行い，同時刻に 3 回実施 した. また，直接採取も同じ場所でほぼ同時刻に行った。

図-6に可搬型八イドロフォンで得られた結果から， Method 1 で得られた最大パルス数に対する Method 2 で得 られた全 Chのパルス数の総和の比（図中の○）と各 $\mathrm{Ch}$ で Method 1 から求めた Method 2 のパルス数に対する Method 2 のパルス数の比（図中の $\triangle ） を$ 示寸. どちらか のパルス数がゼロになる場合は, 割合をゼロにした. 図 中の $\mathrm{Ch}$ は増幅率を示し, 数值が大きいと増幅率が小さ く, 同じ $u^{*}$ の条件下では, 増幅率は粒子径である程度評 価することができる ${ }^{10)}$.これらの結果より，Method 1 は Method 2 よりも全時刻でパルス数が少なく記録される.

Method 1 から Method 2 のパルス数と Method 2 のパルス数 を比較すると, Ch5 や Ch6 では全時刻で割合が 1 もしく はゼロになるが，その他の Ch は 1 よりも大きい. 特に,
Ch1 では計測 10 分後に, Ch4 では計測 1 時間〜 1 時間 30 分後に割合が 1.5 を超える場合がある.Chの特性を考え ると, 計測直後は細かい砂礫が，計測後 1 時間後は比較 的粗い砂砂がハイドロフォンに衝突したと考えられる.

Method 1 から Method 2 のパルス数を求めても Method 1 の方がパルス数が少ない. 各 Ch の比が 1 にならない理 由は, 計測間隔が影響すると考えられる. 例えば，図-7 のような衝突が高頻度の波形では, 衝突頻度が高くなる と波形が閾值を下回る前に次の粒子が衝突して，その閾 值ではパルスが記録されず，Method 1 で最小の閾值でパ ルス数が最大にならない場合がある. その場合, 粒子数



図-4＼cjkstart対象区間の縦断図と可搬型ハイドロフォン計測状況.

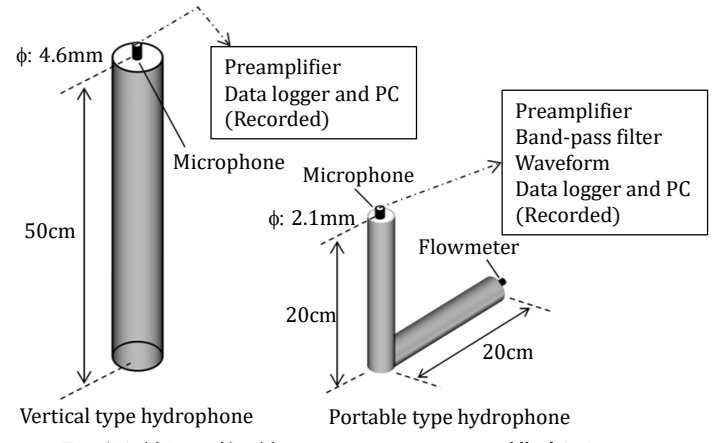

図-5 縦型と可搬型ハイドロフォンの模式図.

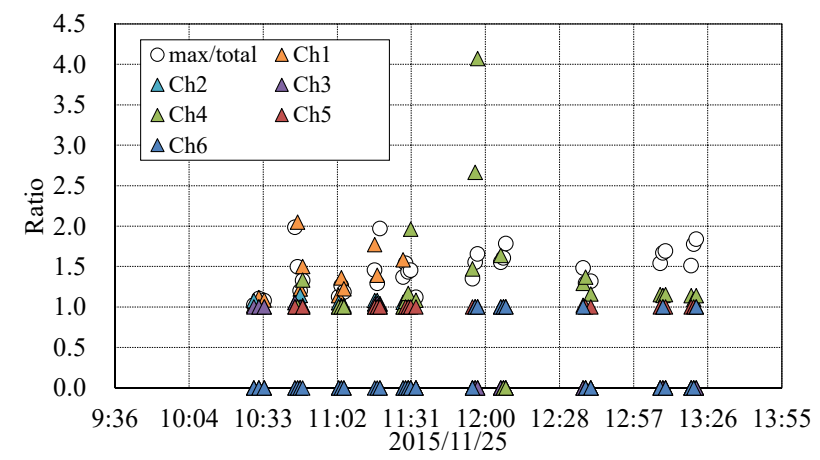

図-6＼cjkstart解析手法の違いによるパルス数の比較.

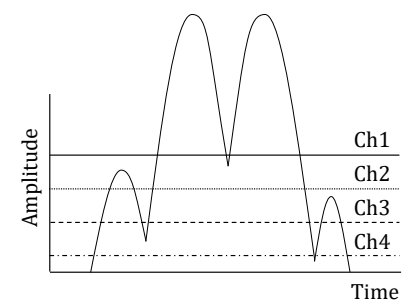

図-7 粒子の衝突が高頻度の音響波形の模式図. 
とパルス数が一致しなくなる. Method 1 では (Ch1, Ch2, $\mathrm{Ch} 3, \mathrm{Ch} 4)=(2,2 ， 3 ， 2)$ と記録される. Method 1 か ら Method 2 のパルス数を求めると（2，0，1，0）である. しかし，実際には Method 2 でのパルス数は，（2，1，1， 0）と Ch2 のパルス数が記録されない. 衝突頻度の違い により, Method 1 から Method 2 のパルス数を求めること ができない，現地で運用されるハイドロフォンは，計測 間隔が数分間に設定されるているため, Method 1 での解 析がパルス数を少なくする原因の一つと考えられる.

Method 2 で求めたパルス数から流砂量を推定した. 解 析手法の詳細は既往研究 ${ }^{10)}$ を参照されたいが，必要な情 報は，衝突する粒子が持つ運動量と振幅值の関係，水理 条件である. 図-8 に可搬型ハイドロフォンと直接採取 した流砂量の結果を示す. 両者ともに 11:30 まで流砂量 がほぼゼロなのに対して，それ以降の時刻では流砂量が 増大する. しかし, 両者の值は異なり, ハイドロフォン ではピークが出現した後に徐々に減少傾向を示し，直接 採取では徐々に増加傾向を示した後にピークが出現する. 解析手法にはハイドロフォンへの衝突率を考慮していな いが，今回の観測では水深が 4〜 $5 \mathrm{~cm}$ と小さく，手持ち でハイドロフォンを流砂の衝突させやすい位置に置いた ため, 衝突率の影響は小さい. 山地河川では短時間で局 所的に流れの変化が現れやすく, 計測箇所や時刻が少し 異なるだけで，明らかな差が生じたと考えられる.

\section{4. 流砂観測データを用いた河床变動計算の検証}

\section{(1) 計算概要}

掃流砂を対象とした混合粒径の数值シミュレーション を行った. 松本ら ${ }^{11)}$ の提案したモデルで一次元計算領域 だけを採用したもので，高橋モデル 12),13)を基に侵食堆積 を計算する方法である.

\section{（2）計算条件}

供給流量は $0.05 \mathrm{~m}^{2} / \mathrm{s}$ 一定とした。供給流砂量は, 縦型 ハイドロフォンで計測した波形を基に設定したが前章に 記載したように定性計測に留まり，観測時間の移動土砂 量は明らかでない. 総排砂量 $21.8 \mathrm{~m}^{3}$ の大部分は試験堰堤 直下で堆積したが，堆積量も不明で，排砂した土砂の粒 度分布も計測されていない。

縦断形状は測量して，河道幅は現場状況から一律 $2 \mathrm{~m}$ とした. 観測 (計算) 範囲の移動可能土層厚や粒度分布 は計測されていないが，大部分でアーマーコートが確認 された. 結果の検証には，3 章で検討した可搬型ハイド ロフォンの結果を利用した。計算は，試験堰堤から下流 約 $150 \mathrm{~m}$ までを対象としたが，結果の比較は流砂観測を 行った落差工地点とした.

土砂の粒度分布, 移動可能土層厚は十分な情報がない
ため, いくつか仮定を行った. 土砂の粒度分布は, 平均 粒径 $(5.6 \mathrm{~mm})$ を設定 $\left(\mathrm{S}_{1}\right)$ ，直接採取で観測された 8 粒径階 $(23,11 ， 5.7,2.8,1.4,0.71,0.35,0.18 \mathrm{~mm})$ を設 定 $\left(\mathrm{S}_{2}\right)$ ，アーマーコートを確認したことから 8 粒径階

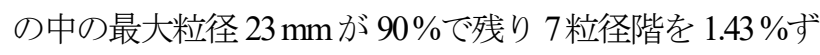
つ設定 $\left(\mathrm{S}_{3}\right)$ ，の 3 種類を行った. 移動可能土砂厚は固 定床，渓流全体を $0.5 \mathrm{~m}$ の移動床を検討した。計算点間 隔は，微地形等を表現できるよう $0.5 \mathrm{~m}$ とした。本計算 ではステッププールは地形条件としてのみ表現される. その他の計算に用いたパラメータを表-1 に示す. 計算 対象は，10:15-13:45 までの 3 時間半とした. 上流端から 供給する水と土砂の境界条件は 3 種類のシナリオを検討 し，数值シミュレーションのケースを表-2に示す.

Supply1 では，上流側に $5 \mathrm{~m}$ 上流端と同じ勾配（河床表

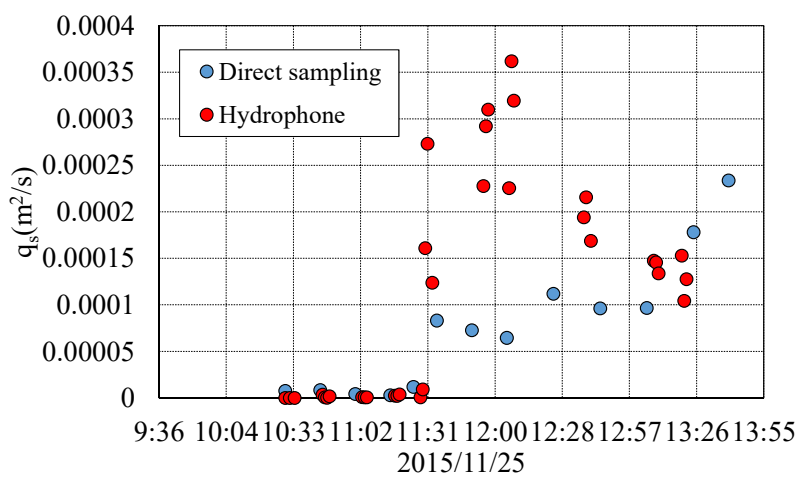

図-8 直接採取と可搬型ハイドロフォンから推定した流砂量.

表-1 数值シミュレーションに用いたパラメータ.

\begin{tabular}{l|l}
\hline Parameters & Value \\
\hline \hline Simulation time $(\mathrm{s})$ & 12,600 \\
\hline Time interval $(\mathrm{s})$ & 0.1 \\
\hline Simulation interval $(\mathrm{m})$ & 0.5 \\
\hline Sediment density $\left(\mathrm{kg} / \mathrm{m}^{3}\right)$ & 2,650 \\
\hline Fluid phase density $\left(\mathrm{kg} / \mathrm{m}^{3}\right)$ & 1,000 \\
\hline Volumetic concentration of riverbed sediment $C_{*}$ & 0.65 \\
\hline Internal frictional angle of sediment tan $\phi$ & 0.7 \\
\hline Gravitational acceleration $\left(\mathrm{m} / \mathrm{s}^{2}\right)$ & 9.8 \\
\hline Coefficient of erosion velocity $\delta_{e}($ standard $)$ & 0.0007 \\
\hline Coefficient of deposition velocity $\delta_{d}$ & 0.05 \\
\hline Manning's roughness coefficient $n_{m}\left(\mathrm{~s} / \mathrm{m}^{1 / 3}\right)$ & 0.03 \\
\hline
\end{tabular}

表-2 数值シミュレーションのケース.

\begin{tabular}{|c|c|c|c|c|}
\hline Run & $\begin{array}{l}\text { Upstream } \\
\text { supplied condition }\end{array}$ & Riverbed & Sediment & $\begin{array}{l}\text { Erosion } \\
\text { coefficient }\end{array}$ \\
\hline$\overline{10}$ & \multirow[t]{6}{*}{ Supply 1} & \multirow[t]{6}{*}{$\overline{\text { fix }}$} & $\mathrm{S}_{1}$, uniform & 0.0007 \\
\hline 2 & & & $\mathrm{~S}_{2}, \operatorname{mix}$ (equal) & 0.0007 \\
\hline 3 & & & $\mathrm{~S}_{1}$, uniform & 0.00007 \\
\hline 4 & & & $\mathrm{~S}_{2}, \operatorname{mix}$ (equal) & 0.00007 \\
\hline 5 & & & $\mathrm{~S}_{1}$, uniform & 0.000007 \\
\hline 6 & & & $\mathrm{~S}_{2}, \operatorname{mix}($ equal) & 0.000007 \\
\hline$\overline{7}$ & \multirow[t]{6}{*}{ Supply 2} & \multirow[t]{3}{*}{ fix } & $\mathrm{S}_{1}$, uniform & 0.0007 \\
\hline 8 & & & $\mathrm{~S}_{2}, \operatorname{mix}$ (equal) & 0.0007 \\
\hline$\overline{9}$ & & & $\mathrm{~S}_{3}, \operatorname{mix}(23 \mathrm{~mm}, 90 \%)$ & 0.0007 \\
\hline 10 & & \multirow[t]{3}{*}{ movable } & $\mathrm{S}_{1}$, uniform & 0.0007 \\
\hline 11 & & & $\mathrm{~S}_{2}, \operatorname{mix}($ equal) & 0.0007 \\
\hline 12 & & & $\mathrm{~S}_{3}, \operatorname{mix}(23 \mathrm{~mm}, 90 \%)$ & 0.0007 \\
\hline 13 & \multirow[t]{2}{*}{ Supply 3} & \multirow[t]{2}{*}{ fix } & $\mathrm{S}_{1}$, uniform & 0.0007 \\
\hline$\overline{14}$ & & & $\mathrm{~S}_{2, \operatorname{mix}(\text { equal) }}$ & 0.0007 \\
\hline
\end{tabular}


面を同じ勾配）で延長して，その区間に $2.18 \mathrm{~m}$ 厚で土砂 を敷く．延長区間以外は固定床とした．実験や計算で用 いる侵食区間を上流に設定したシナリオである.

Supply2 では，縦型ハイドロフォンの波形を基に，上 流端から土砂量 $21.8 \mathrm{~m}^{3}$ を供給した。 ここでは, 供給土砂 及び移動床の条件として 3 についても検討した.

Supply3 では, 排砂土砂の大部分は堰堤直下に堆積し て排砂量の $1 / 10\left(2.18 \mathrm{~m}^{3}\right)$ が流出したと仮定した.ここでは, 混合粒径の設定は均等割合の夕を実施した。 図-9に各 条件の上流端からの供給ハイドログラフを示す.

\section{a) 計算結果 (Supply1) と観測結果}

図-10 に計算結果（Supply1）と観測結果の比較を示す。 計算結果から，いずれも早い段階で流出寸る流砂量が非 常に多く, 後半になると減衰する. 侵食速度係数を $1 / 10$

(Run3，4），1/100（Run5，6）と小さくすると $\mathrm{S}_{2}$ の条 件では最初の立ち上がりは下がるが，徐々に減衰する傾 向を示寸のは同様で，可搬型八イドロフォンで得られた ような途中で流砂量が大きくなる波形は見られない.

\section{b) 計算結果（Supply2）と観測結果}

図-11 に計算結果（Supply2）と観測結果の比較を示寸。 移動床では，全ての条件で，計算初期で一気に侵食が進 み11:00 以降まで減少した後に，12:00～12:30 頃に流砂量 が多くなる傾向が見られ，中盤での立ち上がりは観測結 果と対応した. しかし，10:30 頃や中盤での流砂量は観 測結果と比べてオーダー単位で計算結果の方が大きい. 固定床の平均粒径，均等割合の混合粒径を供給した結果 では，初期の急激な流砂量の増加は見られずに，11:15 頃に最初のピークを迎えた後，12:00〜12:30 頃に最大の ピークが出現してその後は減衰する傾向は観測結果と対 応するが，中盤では計算結果の方が大きい. 固定床で $\mathrm{S}_{3}$ で供給したケース（Run9）では，現地実験と同様に上 流端の直下で堆積が発生して，12:00 過ぎに見られる流 砂量のピークは $\mathrm{S}_{2}$ （Run8）よりも若干少なくなる.

\section{c) 計算結果 (Supply3) と観測結果}

図-12 に計算結果（Supply3）と観測結果の比較を示寸. 平均粒径，混合粒径とも計算結果と観測結果が示寸中盤 でのピーク值が最も近くなり, 中盤で流砂量が増加する 傾向も対応した．一方で，10:30～11:00 までの流砂量は 計算結果の方が大きく, 中盤のピーク以降では観測結果 の方が徐々に減衰するのに対して計算結果では 13:00 以 降の流砂が確認されない点は異なる.

計算結果から，山地河川で平常時に近い状態では，ア ーマーコートにより河床の土砂移動が殆どない固定床状 態に近く, 上流から流入した土砂が下流に流動すること が示され，既往検討 ${ }^{14)}$ とも合致する. そのため，上流か
ら流入する流砂量の時系列的な情報, 対象期間に移動し た正確な土砂量，さらには粒度分布が必要だと示された。 本検討では, 結果を検証するための流砂量データは存在 したが，供給流砂量は期間中の移動量や粒度分布が不明 だったため，いくつかの仮定に基づき条件を設定した. しかし，土砂ハイドロの情報も存在しない場合は，Supply1 のような大胆な仮定や平衡給砂を設定することにな るが，山地河川の流砂量は平衡土砂量と比較して圧倒的 に少なくこの方法では過大評価に繋がることが多い，よ り正確な情報を用いて下流への伝播を議論するには, 時 間・空間的に連続した情報が不可久である.

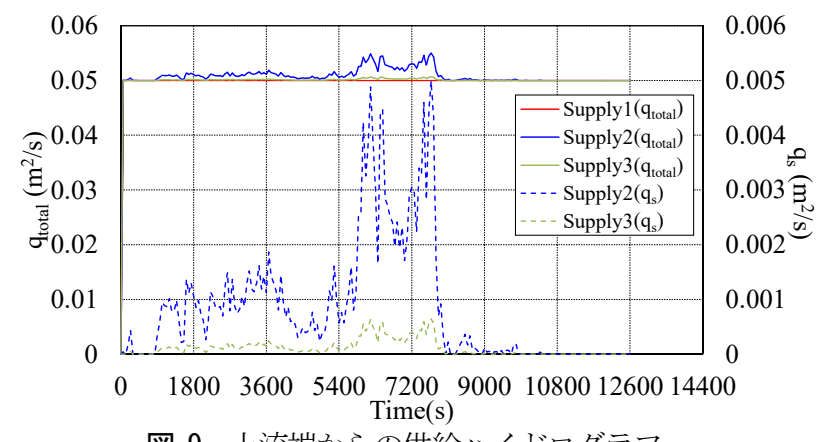

図-9 上流端からの供給ハイドログラフ.

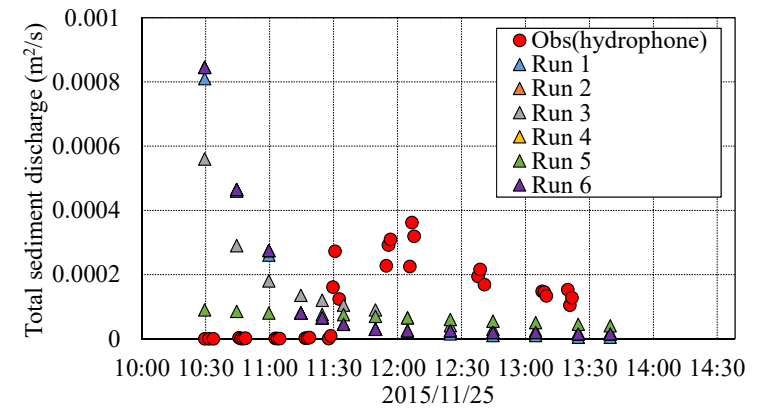

図-10 計算結果（Supply1）と観測結果の比較.

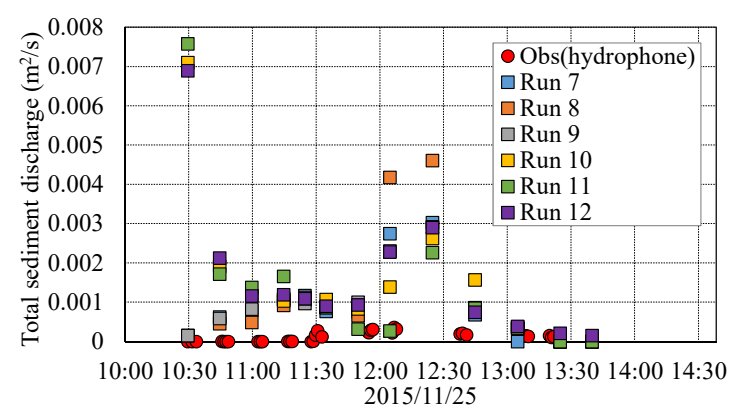

図-11 計算結果（Supply2）と観測結果の比較.

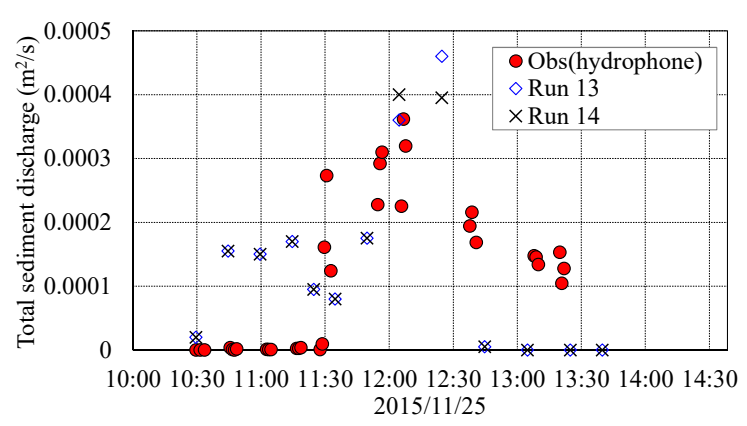

図-12 計算結果 (Supply3) と観測結果の比較. 


\section{5. おわりに}

本研究では，ハイドロフォンによるパルス数の記録方 法の検討並びに流砂観測より得られたデータを基に数值 シミュレーションを実施し，計算と観測を連携させるた めに必要な情報の整理を行った，以下に成果をまとめる

1) ハイドロフォンの記録方法には，全ての閾值でパル スを記録する方法と最大閾值でパルスを記録する方 法がある。現地ではほとんどが前者の方法が採用さ れるが，流砂量が多い状態ではパルスが記録され難 く後者の方法が有効であることを明らかにした。

2) 現地観測データと数值シミュレーション結果の比較 から，地形条件や流量の他に，上流端からの流砂量 の供給条件，粒径，河床条件が必要であることを示 した.

3）本計算では，供給流砂量が最も影響することを示し た．現地観測には様々なデータが必要だが，流砂量 を複数の断面で正確に把握すると計算結果の精度も 向上すると考えられる.

山地河川での土砂移動は非平衡性が強く, 理論や計算 上で仮定する平衡流砂量が流出することは殆ど無いと推 測されるが，定量的な検討やデータの蓄積が少ない。本 検討で示した高精度な解析手法の提案や観測技術の向上 と合わせて，時間・空間的に連続した流砂データの蓄積 を行い，解析と検証の進展が今後期待される.

謝辞 : 本研究は，科研費 $16 K 01326$ の 助成を受けたもの です。ここに記して感謝致します。

\section{参考文献}

1) 建設省土木研究所，掃流砂量観測， 1970

2) 沢田豊明：山地河川における土砂流出の観測研究— 観測法と計測機器一，京都大学博士論文「山地流域 の土砂流出に関する研究」, 1985
3）谷口伸一，板倉安正 : 音響法による流砂量計測のた めの信号解析，滋賀大学紀要（彦根論叢），第 $276 \cdot 277$ 号, pp.323-346, 1992

4）鈴木拓郎，水野秀明，小山内信智，平澤良輔，長谷 川祐治 : 音圧データを用いたハイドロフォンによる 掃流砂量計測手法に関する基礎的研究，砂防学会誌， Vol.62, No.5, pp.18-26, 2010

5) 水山高久, 野中理伸, 野中伸久 : 音響法（ハイドロ フォン）による流砂量の連続計測, 砂防学会誌, Vo.49, No.4, pp.34-37, 1996

6) 水山高久，野中理伸，藤田正治：常願寺川津之浦下 流砂防堰堤におけるハイドロフォンによる流砂観測, 砂防学会誌，Vol.55，No.3，pp.56-59， 2002

7) 高橋保, 井上素行，中川一，里深 好文 : 山岳流域 における土砂流出の予測，水工学論文集，Vol.44， pp.717-722，2000

8）江頭進治，松木 敬：河道貯留土砂を対象とした流出 土砂の予測法，水工学論文集，Vol.44，pp.735-740, 2000

9) Helley, E.J., and Smith, Winchell: Development and calibration of a pressure-difference bedload sampler, U. S. Geological Survey Open-File Report, 1971.

10）長谷川祐治，宮本邦明：ハイドロフォン内部の音響 特性と流砂量計測に関する実験，砂防学会誌 Vol.66, No.5, pp.23-32，2014

11）松本直樹，和田孝志，中谷加奈，里深好文，水山高 久: 粒径変化を考慮した土石流汇濫予測手法に関す る研究, 砂防学会誌, Vol.65, No.3, pp.3-11, 2012

12）高橋保，井上素行，中川一，里深好文：山岳流域 における土砂流出の予測，水工学論文集，Vol.44, pp.717-722, 2000

13) 中川一, 高橋保, 里深好文, 川池健司：1999 年ベネ ズエラのカムリグランデ流域で発生した土砂災害に ついて 数值シミュレーションによる再現計算と砂防 施設配置効果の評価，京都大学防災研究所年報，第 44 号 B-2，pp.207-228，2001

14) 澤田豊明，芦田和男，高橋保：山地河道における掃 流砂の流送過程，第 25 回水理講演会論文集，pp.507514,1981

(2016. 9.30 受付)

\section{HYDROPHONES ANALYSIS METHOD CONSIDERING SEDIMENT COLLISION FREQUENCY AND APPLICATION TO FIELD}

\section{Yuji HASEGAWA, Shusuke MIYATA, Fumitoshi IMAIZUMI, Kana NAKATANI and Daizo TSUTSUMI}

To measure bedload transportation, analysis method for hydrophone require the acoustic pulse data caused by sediment collision. However, pulses saturation occurs in large sediment discharge condition and underestimation is the problem in hydrophone analysis method. There are two methods to record the pulses; Method 1 using one threshold value with maximum pulses number recorded, and Method 2 using the pulses number with all threshold value. Comparing both methods from field observation data, we proposed a analysis method with less effect of pulses saturation using pulses recorded in Method 2.

Though observation should be associated with simulation to achieve and improve the accuracy, these two are often conducted individually in mountainous rivers. Therefore, we conducted observation and simulation in Ashi-arai-dani using the sediment discharge data estimated with proposed method and organaized the required data for satisfied results in both approch. 